Софија С. Јанић

Филозофски факултет

Универзитет у Новом Саду

Студенткиња мастерских студија

sofija.janic@yahoo.com doi: 10.19090/zjik.2018.145-157

UDK 821.133.1.09 Sartre J. P. прегледни рад

\title{
ЗБИРКА НОВЕЛА ЗИД ЖАН-ПОЛ САРТРА КАО СИМБОЛ НЕМОГУЋНОСТИ ОСТВАРИВАҢА СЛОБОДЕ
}

САЖЕТАК: Зид, једина збирка новела Жан-Пол Сартра, садржи главне елементе његове филозофије: бесмисао егзистенције, концепте самообмане и пакла других те агонију коју изазива терет слободног избора. Немогућност остваривања слободе, чији узроци леже у бекству од егзистенције и комплексном односу са другим који представља препреку ка остварењу аутентичности појединца - тема је овог рада. Свака новела представља вид бекства од егзистенције, бекства која су увек неуспешна јер су заустављена зидом. Ослањајући се на постулате Сартровог егзистенцијализма, рад истражује на који начин су ликови збирке, изоловани и од себе и од других, одрази његове филозофије. Полазна тачка рада је Сартрова идеја да је књижевност облик уништења света у којем је немогуће живети. Зид и јесте деструктиван јер уништава буржоаску концепцију света. Грађански морал представља као лажан пошто служи као препрека слободном испољавању појединца, егзистенцију као апсурдну пошто је коначна, а човекову суштину као непостојећу. За Достојевског све је дозвољено ако бог не постоји. За Сартра ако је сувишно.

Кључне речи: новела, Сартр, егзистенцијализам, слобода, други

\section{СИМБОЛ ЗИДА}

Нико не жели да се суочи са Егзистенцијом. Представљам вам пет повлачења пред њом - трагичних или комичних - пет живота... Сва та бекства су заустављена зидом. Бежати од Егзистенције и даље значи постојати. Егзистенција је пуноћа коју човек на може да напусти (Сартр 1981: 1807).

\footnotetext{
${ }^{1}$ Рад је писан у својству семинарског рада у оквиру предмета Историјска поетика новеле и приче у франиуској књижевности мастер академских студија Романистике, под менторством др Тамаре Валчић Булић.
} 
Сартрова једина збирка новела Зид објављена је 1939. године, недуго након капиталног романа његове филозофије под називом Мучнина. Тема која све новеле уједињује у трагикомичан израз неиздрживости људске судбине јесте немогућност остваривања слободе, чији узроци леже у бекству од егзистенције и другом, који је представљен као препрека слободи индивидуе. А шта је слобода за Сартра?

„Нема детерминизма, човек је слободан, човек је слобода” (Сартр 1981: 267). Слобода је спонтано, неконформистичко делање којим личност ствара своју аутентичност. Она је прелазак од постојања до суштине у филозофији где егзистенција претходи есенциии. Она је сва садржана у драматичном, за Сартра драмском чину слободног избора којим човек себе одређује. Слобода је пуноћа која се рађа из ништавила постојања, јер човек се, по Сартровом атеистичком схватању егзистенције, рађа као биће без сврхе и смисла у свету који је једнако апсурдан. Он није материјализација духовне суштине или производ некакве натприродне силе. Он је апсолутно ништа. Због тога што је ништа, он може да буде све. Из осећања ништавила са једне стране, те свести о безграничној слободи у свету где је све дозвољено, са друге, настаје тескоба Сартрових ликова оличена у вртоглавом осећању слободе и страху од одговорности коју носи слободан избор. Због тога они беже од слободе у лажну, неаутентичну личност, кријући се иза социјалне маске која ће, макар привидно, ублажити њихов неизлечив осећај бесмисла.

Сартрова збирка књижевни је одраз његове филозофије. Ликови Зида оличења су главних елемената Сартрове филозофске мисли: бесмисла постојања, самообмане, пакла других и тескобе слободног избора, повезаних мотивом свеприсутног, разарајућег зида. Деструктиван није само зид већ и сама књижевна уметност која у Сартровој филозофији постаје разарајућа сила: „Не постоји дар приповедања. Постоји потреба за уништењем света кроз писање услед немогућности да се у њему живи" (Сартр 1981: 157). Деструктивни по себе, друге, своју слободу најзад, ликови Зида суштински су одраз потребе за уништењем света у коме је егзистенција мучна а слобода немогућа. А она је немогућа зато што се нико од њих не усуђује да се суочи са мучнином егзистенције.

Свака од новела, по Сартру, представља човеково суочавање са контингенцијом живота и одбијање њеног прихватања, чија је јаловост алегоризована неуспешним покушајем бекства из зидом омеђеног 
простора. Мотив затвореног простора, веома присутан у Сартровим делима, осликава изолацију појединца, која настаје као трагични исход сталних сукоба у људској интеракцији (Јонгенел 2009: 2).

Сартрови протагонисти, бежећи од егзистенције, налећу на метафорички зид који их спречава у остварењу намера, а тиме и слободе. Идеја зида је присутна на најочигледнији начин у првој новели, по којој је збирка и добила име, у којој три лика, заробљеници Франкових фашиста, ноћ пред стрељање, у агонији замишљају зид пред којим ће бити погубљени: „Чини ми се да ћу хтети да продрем у зид, да ћу свом својом снагом гурати зид, а зид ће издржати као када те мучи мора" (Сартр 1980: 14).

У Соби зид има двоструку симболичку функцију: он је метафора раздвојености Еве и њеног полуделог мужа Пјера: „Зид је између тебе и мене. Видим те, говорим ти, али ти си са друге стране" (Сартр 1980: 49), али и затворена соба у којој се Пјер изоловао од спољашњег света. Главни лик новеле Херострат у својој мизантропији затвара се у четири зида своје собе од човечанства. У Интимности зид је соба која за Лулу представља мучнину пред сексуалношћу, али и немогућност остваривања интимности са мужем те зид, као и у Соби, симболише препреку у односу супружника. Симбол зида може да се посматра и у контексту Полових и Лулиних сексуалних инхибиција.

Готово је немогуће размишљати о симболици зида а не помислити на Сартрову драму Иза затворених врата. Међутим, тема затвореног простора није једино што збирку Зид повезује са ремек-делом Сартровог позоришта. Тема комплексног односа са другим који, парадоксално, истовремено побуђује привлачење и одбијање, основна је веза између ових Сартрових дела. Тако се чувено „Пакао, то су Други!” може применити на све четири новеле 3ида.

Од пакла дугих до јединства са другим: пут који ликови Зида никада не пређу

„Други ме посматра (...) Он открива тајну мога бића, зна ко сам” (Сартр 1943: 430). Суочавање индивидуе са спољашњим светом је за Сартра основа егзистенције. У судару бића и егзистенције неминовно се јавља други који представља препреку слободи индивидуе. Тада се може усвојити један од два става: „или ћу уништити другог, или ћу се сјединити са њим и његову слободу укључити у своју” (Кадиш 1975: 45). 
Свака новела Зида на свој начин третира тему другога који је увек приказан као препрека слободи и аутентичности индивидуе: Пабло, протагониста Зида, кроз изолацију од остала два затвореника, али и од лекара који представља живот наспрам његове смрти, уништава другог; Пол, мизантроп из Херострата, изоловао се од људи које он и физички жели да уништи; Ева и Пјер из Собе се одвајају од разумног, здравог друштва; Лулу из Интимности бежи од других одбацивањем сексуалности, али у овој новели други је представљен и као манипулатор туђе (Лулине) свести и слободе избора, спречавајући остварење аутентичности. С обзиром на то да их други спречава у испољавању слободе и аутентичности, ликови Зида усвајају антагонистички став према њему, теже његовом уништењу пошто не успевају да се сједине са њим. „Деструкција је последица непроживљеног живота” (Фром 1989: 193), те се протагонисти збирке, не успевајући да се остваре као слободне личности, окрећу уништењу.

Комплексност односа са другим у заједници, која је истовремено и уточиште и пакао, представљен је на сличан начин у Соби и Интимности пошто се у оба случаја јавља брачни пар. Брак у обе новеле доказује примарну људску потребу за јединством са другим. У Соби Ева жуди за јединством са својим полуделим мужем, као вид бекства од лажног, неаутентичног, буржоаског друштва, оличеног у њеним родитељима. У Интимности Лулу остаје крај свог импотентног мужа који за њу представља утеху и спас од мучне сексуалности оличене у љубавнику. Занимљиво је да и Евин и Лулин брак представљају врсту самообмане пошто се суштински показују као неаутентични (Пјер, Евин муж бира лудило као бекство од егзистенције, док је брак између Хенри и Лулу само привид, пошто је заснован на сажаљењу и превари) и служе једино као уточиште од агоније слободног избора. Но, Ева и Лулу својим изборима на крају уништавају другог: Ева изјављује како ће убити мужа пре него што му се ум потпуно помрачи, док Лулу остаје у браку са Хенријем, прихватајући његов недостатак љубави према њој и његову импотенцију, чиме га своди на ниво објекта, пошто се сједињење у физичком и духовном смислу неће остварити. Ипак, Лулу и поред брака бира да и даље наставља да се виђа са љубавником Пјером, доказујући да није способна да учини коначан избор и тиме у потпуности дефинише своју личност: потпуно одбацивање или сједињење са другим.

Самоћа није решење будући да постоји потреба за другим, са којим истинска веза није могућа. Сартр и у Зиду и у Иза затворених врата осликава 
паклени зачарани круг односа са другим: са једне стране, други је основа егзистенције пошто једини може да потврди постојање појединца, али, са друге стране, стварна комуникација и аутентични однос лишен самообмане са другим не може се остварити. Управо због тога Сартрови ликови никада нису ни потпуно сами али ни потпуно уједињени са другим. Они остају на пола пута између изолације и интеграције.

Евино полурешење се огледа у њеној одлуци да убије мужа, те пошто до њихове заједничке слободе неће доћи, Ева ће остати на пола пута између неаутентичне егзистенције буржоаског друштва и остварења своје аутентичности. Ипак, од свих ликова Зида, Ева је једина код које је назире истинска, дубока потреба за аутентичношћу. У том погледу она је сушта супротност Лулином конформизму и привиду нормалности.

Кроз ликове Еве и Лулу уочава се контрадикторан однос са другим: обе су се изоловале од друштва које отеловљује претњу, непрестан поглед, но „порив ка супротности изолације, ка интеграцији и даље постоји” (Кадиш 1975: 46). Ни једна ни друга не одбијају контакт са друштвом: Ева, иако одбија да буде део буржоаског миљеа, редовно се виђа са својим оцем, оличењем грађанског морала, док Лулу ни на крају новеле не одбацује љубавника, а ни пријатељицу Рирет, иако обоје у њој буде мржњу и спречавају њено самоостварење.

Приметићемо да је у обе новеле веза са другим представљена у оквирима затвореног простора: Ева се придружује мужу у соби, а оцу у салону, које везује ходник, метафора лимба у којем она живи: између разума тј. друштва и лудила тј. изолације. Лулу се и са љубавником и са мужем састаје у полумраку собе, која у првом случају изазива гађење пред сексуалним чином, а у другом, свест о мужевљевој импотенцији.

„Спољни свет интеграције оличен је у отвореном, светлом простору” (Кадиш 1975: 47). Исти тај отворени простор, преплављен људима, представља сигурност за Евиног оца: „На тим осунчаним улицама, међу људима, осећаш се сигурним, као у великој породици" (Сартр 1980: 43) и место састајања Лулу и Рирет, представником друштва у којем Лулу жели привидно да припада.

Док Лулу и Ева остају на пола пута између изолације и интеграције, Пабло Ибиета из Зида се одлучује за изолацију, те је једини лик збирке који готово до краја истрајава у свом избору одвојености од другог. Осећајући на 
почетку извесну припадност групи и емпатију према Тому и Хуану, са којима је ухапшен као противник Франковог фашизма, Пабло постепено развија став потпуног одвајања од својих доскорашњих сабораца, увиђајући да су њих тројица „огледала један другоме” (Сартр 1980: 18). Као и паклени трио у Иза затворених врата, тројица затвореника заробљени су у једној просторији и повезани заједничком судбином из које нема излаза. Иако је претећи поглед другог оличење пакла, Паблу је, као и ликовима драме, он болно потребан да би доказао сопствено постојање.

Смрт у Зиду, уместо да уједини, ствара непремостиви јаз између Пабла и другог. Она побуђује свест о апсурду живота услед које се и веза са другим приказује као бесмислена: „ничији живот није имао вредности. Поставиће човека уза зид, пуцати у њега док не цркне; да ли ћу то бити ја, или Грис, или неко други, свеједно је" (Сартр 1980: 24). За Пабла други постају огледало агоније смрти коју он одбацује. Гади се заривања бајонета у Томово меко месо и Хуановог хистеричног плача, јер за њега оваплоћују неизбежну смрт. Готово да одбија да говори са свештеником, који ту није као божји изасланик већ посматрач њихових тела „која су жива умирала” (Сартр 1980: 21). Пабло презире заједничку патњу и јединство са другим пред смрћу. Он не жели да умре као животиња већ жели да разуме смрт коју је немогуће појмити: „Човек није створен да о томе мисли" (Сартр 1980: 15). Окретање ка интроспекцији код Пабла узрокује одвајање од физичког. То одвајање је оличено одбијању да његово тело, за разлику од Томовог и Хуановог, ода знаке страха пред смрћу. Пабло одбацује своје тело и због других: оно је спољашња представа његовог бића које служи да би га други видели. Повлачећи се у своју унутрашњу свест и одбацујући тело, он одбацује другог. Исто одбацивање догађа се и код Лулу, чије тело представља извор сексуалног задовољства другог: „Одвратно је то, зашто морамо имати тело?” (Сартр 1980: 80).

Повлачење у строго омеђене границе свести и простора, најочигледније је Херострату где Пол Ибер, гоњен дубоком мржњом према човечанству, у потпуности одбацује друштво и жуди за његовим физичким уништењем: насумичним пуцањем у пролазнике на улици. Поново се појављује симбол улице као отвореног простора где се одиграва сусрет са другим. Други су препрека његовој слободи, пошто у друштву Пол не може да оствари аутентичност. Одбацујући друштво као извор неаутентичности (као Ева), Пол бежи у изолацију, која се показује једнако неаутентична као и друштво. 
Пол, наиме, и према самом себи има однос са другим, доживљавајући себе истовремено као индивидуу и као другог. На почетку новеле изјављује: „Поставио сам се изнад људског што је у мени и посматрам” (Сартр 1980: 57). Мотив нељудског појављује и код Пабла: „Погледао сам Хуана, угледао његова мршава уздрхтала рамена и осетио се нељудски; нисам се могао сажалити ни над другима ни над собом" (Сартр 1980: 21), али и код Еве и Пјера: „она живи изван свега људског. Пјер више није људско биће” (Сартр 1980: 43), закључује њен отац. Одбацивањем људског у себи Сартрови ликови се повлаче пред тескобом слободног избора.

Пол попут Лулу на крају не издржава потпуну изолацију од другог: пуцајући на насумичног пролазника, гоњен гомилом, затвара се у кабину јавног тоалета (поново симболика затвореног простора) и одустаје од првобитне намере да се убије, отварајући врата и предајући се другима. Смрт би за њега представљала потпуну изолацију. Његова предаја другима као и чињеница да је сам наратор Херострата, којег пише као врсту исповести непознатој публици, другима, „омогућава му исти привид интеграције у изолацији, који је Лулу остварила" (Кадиш 1975: 51). Иберу су други потребни као публика: „Публика је једно ишчекивање, једна празнина коју треба попунити, једна аспиращија. Једном речи, публика то је други” (Сартр 1981:57). Парадокасалност односа са другим огледа се и у Половим противречним ставовима: са једне стране, он се крије од других затварајући се у собу, док са друге, он жуди да га они виде и тиме му пруже потврду његове егзистенције. Он себе поистовећује са Херостратом који је запалио храм у Ефесу само да би његово име остало записано у историји. Пол убија да би га други запамтили.

Однос са другим представљен је градацијом од скоро потпуне изолације у првој новели, Зиду, до привида интеграције у Интимности. Ипак, нико од ликова не остварује у потпуности ниједно од два супротна стања. Оно што их спречава да се одреде је неаутентичност којом они беже од егзистенције, а самим тим и од слободе.

\section{ЗИД: ИЗРАЗ НЕАУТЕНТИЧНОСТИ}

Кроз самообману ликови Зида крију од себе тескобну чињеницу да су слободни. Они развијају моделе понашања којима беже од слободе у неаутентичну егзистенцију. Поистовећивањем појединца са друштвеном улогом настаје неаутентичност. Сартр овом збирком илустује и једну од својих главних филозофских идеја: питање аутентичности и њене могућности у 
друштву. „Повлачење у себе којим се између појединца и непријатеља оличеном у другом подиже зид, једнако је лоше и половично решење као и потпуно рушење истог зида и бекство у масу које имплицира губитак аутентичности" (Сартр 1995: 12). Кроз лик Пола Ибера најбруталније је приказан раскол између индивидуе и друштва: њему је немогуће да оствари аутентичност у друштву, речи којима се служи припадају другима и он их користи са гађењем. „Не волим људе, бедник сам, и не могу себи наћи место под сунцем. Они су себи присвојили смисао за живот" (Сартр 1980: 66).

Полова и Евина самообмана имају исти извор: егоцентризам. „Ева је поносна што нигде не припада, а њена љубав према Пјеру потиче из егоцентричне жеље да посматра себе док игра улогу” (Симон 1964: 536), Полова мржња према човечанству плод је његовог охолог става да је морално надмоћнији од других: „На балкону шестог спрата, ето ту је требало да проведем читав свој живот. Моралну надмоћ треба подупирати материјалним симболима иначе се она губи" (Сартр 1980: 57). Попут Лулу која изјавом да „никада, никада човек не чини оно што хоће, ветар га носи” (Сартр 1980: 106), одбацује одговорности за своје поступке, Ибер чини исто говорећи: „Не могу да их волим, тако сам рођен” (Сартр 1980: 66). Оба лика, тражећи узроке своје неаутентичности у спољашњим елементима уместо у себи, развијају самообману. Лулина неаутентичност осликана је њеним избором да остане поред мужа чија импотенција на њу делује утешно, услед њене згађености над љубавниковом сексуалношћу. Она се лако предаје туђим манипулацијама из страха од одговорности коју носи слободан избор. Као и Пол, Лулу дубоко мрзи људе око себе, али свој презир крије иза маске љубавнице и жене која би се жртвовала за мужа, одржавајући тиме привид нормалности. Наспрам Лулине илузије нормалности, налази се Пјерова илузија лудила, којима је неаутентичност заједничка.

Сартров став према Пјеровом лудилу повезан је са филозофовим одбацивањем Фројдове теорије по којој несвесно управља људским понашањем. Теорија несвесног, по Сартру, одбацује значај слободне воље који је капиталан у егзистенцијализму. Сартр сматра да је подсвест лажна и да није ништа друго до вид самообмане.

Одбијајући конформистички миље својих родитеља, Ева на Пјерово лудило гледа као на аутентичну побуну против лажног и лицемерног буржоаског друштва оличеном у њеном оцу Шарлу. Затворени и нестварни 
Пјеров свет у који Ева безуспешно жуди да продре није ништа друго до варка и привид, пошто су, по Сартру, сви лудаци лажови. Кроз Евину одлуку на крају новеле да убије мужа пре него што он потпуно полуди, огледа се и Сартров став према неаутентичности лудила: „Као и Ева, Сартр одбија да прихвати лудило и да се преда несвесном" (Симон 1964: 65). Ментална болест није алтернатива конформистичком буржоаском животу пошто и сама представља вид конформизма својим одбијањем одговорности слободног избора. Лудило води у дегенерацију и неартикулисаност која своди човека на објекат, а не чини од њега свесно биће обдарено слободном вољом како га Сартр види. Ева се својим коначним одбацивањем лудила посредно одлучује за здраво друштво те ће, као и Лулу, припадати свету где влада илузорни грађански морал, а у којем је заправо све дозвољено.

Сартров свет: да ли морал постоји ако је све је дозвољено?

Достојевски је написао: Ако бог не постоји, све је допуштено. То је полазна тачка егзистенцијализма. У ствари, све је дозвољено ако бог не постоји, и према томе човек је напуштен јер не налази ни у себи ни изван себе могућност да се ослони [...] Не може више бити а приори доброга, јер нема бескрајне и савршене свести да га мисли; нигде није записано да добро постоји, да треба бити поштен [...] (Сартр 1981: 267).

У светлу Сартрове негације постојања бога, може се анализирати новела Зид у којој бесциљни чин протагонисте настаје као одговор на устројство света где је све дозвољено. Смрт се јавља као подстрекивач свести о бесмислу живота услед његове коначности: „У том ми се часу учинило да је цели мој живот преда мном, и мислио сам: то је проклета лаж. Он је био безвредан јер је био завршен" (Сартр 1980: 18). У Зиду све је дозвољено зато што бог не постоји и зато што умиремо. Као и Калигула из Камијеве истоимене драме, који живот види као апсурдан пошто људи умиру и због тога од своје потпуне слободе прави иживљавање, тако и Пабло од свог слободног избора прави фарсу. Да би се смејао. Да би апсурдом свога избора узвратио ударац бесмислу постојања. Педро је стављен пред избор који ће га одредити: или ће одати скровиште анархистичког вође Рамона Гриса или ће бити убијен. Педро из шале говори Франковим фашистима да се Грис налази на гробљу, но убрзо доживљава апсурдни преокрет судбине: сазнаје да су војници заиста пронашли Гриса на гробљу и убили га. „Смејао сам се тако гласно да су ми сузе врцале из очију” ( Сартр 1980: 30). Паблов смех подсећа на смех којим се завршава драма Иза затворених врата, када Инес, Гарсан и Естел почињу да 
се смеју схвативши да су заувек осуђени једно на друго: „Заувек! Боже како је то смешно!” (Сартр 1976: 94). Као ни ликови драме, ни Ибиета не може да прекине везу са другим, иако стремио ка потпуној изолацији.

Паблов избор симболише Сартрову идеју да је све дозвољено у свету без бога, укључујући и иживљавање над слободом и њено претварање у фарсу. Приметићемо да се уосталом ниједан од ликова збирке не преиспитује о моралној исправности својих избора и поступака. Пол Ибер, у свом нагону за убијањем, ниједног тренутка не размишља о свом чину са моралне тачке гледишта, као ни Ева када одлучује да ће убити мужа.. Грађански морал Евиних родитеља приказан је као ускогруд и неаутентичан. Лулу не размишља да је њена превара можда неморална, јер „док год је називају госпођом, она мисли да то није важно" (Сартр 1980: 80). Ипак, Лулу у себи сједињује противречност потребе за постојањем морала и његове немогућности. Она жуди за чистотом у прљавој сексуалности, „за лепим младићем, невиним као девојка, са којим би у брачној постељи спавала као сестра” (Сартр 1980: 92). Ликови Зида живе у свету где „нигде није записано да добро постоји, да треба бити поштен" (Сартр 1981: 267), те немајући спољашњег ослонца у виду морала, осуђени су да сами изграде своју слободу која више није условљена постојањем а приори доброг или лошег. Више нису марионете у рукама бога, већ апсурда постојања које са собом не носи никаква правила. Непостојање моралних правила истовремено представља и апсолутну слободу и терет који она са собом носи. Протагонистима би било лакше када би могли да нађу спољашњи ослонац који би условљавао ьихове изборе. Због тога се Лулу предаје Риретиним манипулацијама и пушта је да одлучује уместо ње, док Пол кроз своју исповест тражи разумевање читаоца кроз оправдавање својих поступака. Они жуде за потврдом другога који би одлучио о исправности њихових избора. Они познају божанску неодговорност осуђеника на смрт (Лует 2013: 25) у егзистенцијалистичком поимању света где је све допуштено.

\section{ЗАКљУЧАК}

Збирком Зид Сартр руши буржоаску концепцију света: грађански морал представља као лажан пошто служи као препрека слободном испољавању појединца, егзистенцију као апсурдну пошто је коначна и сувишна, а човекову суштину као непостојећу пошто нема свемогуће силе која би је створила. Припадност истом том буржоаском друштву симболише неаутентичност пошто се индивидуалност утапа у маси и предаје владајућем 
конформизму. Ипак, ни изолација није решење, пошто „било како било, ми ипак живимо међу људима" (Сартр 1980: 43). Ликови збирке су, свако на свој начин, отпадници друштва пошто је други препрека њиховој слободи и аутентичности. Они не могу да се остваре у свету где су непрестано изложени пакленом погледу другог који је разоран по њихову слободу. Док затворени простор у Иза затворених врата симболише пакао, у Зиду је он једино уточиште од света у којем је људска судбина неиздржива, уточисте једнако паклено као и у драми. Ликови Зида који нису ни потпуно изоловани али ни потпуно сједињени са другим, остају у лимбу између остварења слободе и њене немогућности услед неаутентичности у којој живе. Њихова свест растрзана је између живота и смрти, другог и изолације, разума и лудила, чедности и сексуалности. Тај дубоки раскол заједнички је свим ликовима збирке, чија трагедија настаје неуспелим покушајима бекства од пуноће егзистенције. Бекством од егзистенције бежи се и од слободе. Пабло бежи од егзистенције покушавајући да појми смрт и предајући се њеном деструктивном дејству, Ева и Пол жељом за повлачењем од друштва у којем је немогуће живети, док се Лулу повлачи пред слободним избором својом неспособношћу да издржи његову агонију. Представљена су различита решења пред проблемом остварења слободе. Четири бекства од егзистенције, сва четири једнако неуспешна. На крају Зида остаје суштинско питање: Ако човек не може нити да побегне од егзистенције, нити да издржи агонију слободног избора у свету у којем је све дозвољено, како да оствари своју слободу?

Осећам се лагодно само у слободи кад измичем предметима, кад измичем себи самом...

Ја сам истинско ништавило пијано од гордости и прозрачно.. А то је и свет који хоћу да поседујем (Коен-Солал 2007: 1). ${ }^{2}$

\section{ЛИТЕРАТУРА}

Женет, Жерар. 1985. Фигуре. Београд: Вук Караџић.

Зуровац, Мирко. 1986. Умјетност као истина и лаж бића. Нови Сад: Матица српска.

\footnotetext{
${ }^{2}$ Коен-Солал цитира на почетку своје књиге Сартрове стихове из Бележнице од смејурије од рата.
} 
Коен-Солал, Ани. 2007. Сартр (1905-1980). Нови Сад: Издавачка књижарница Зорана Стојановића.

Сартр, Жан-Пол. 1980. Зид и друге приповетке. Београд: Издавачка радна организација „Рад”.

Сартр, Жан-Пол. 1981. Филозофски списи. Београд: Нолит.

Сартр, Жан-Пол.1981. Шта је књижевност. Београд: Нолит.

Тарле, Јере.1982. Повјест свјетске книжевности. Загреб: Младост.

Фром, Ерих. 1989. Бекство од слободе. Београд: Нолит.

$$
* * *
$$

Baudelaire, Charles. 1880. L'Art romantique. Paris: Calmann-Lévy.

Helkkula, Mervi. 2009. Narration omniscient ou récit sans narrateur?.https://www.cairn.info/revue-poetique-2009-4-page-397.html (21. 06. 2017).

Jongeneel, Els. 2009. Madness in Sartre's Room. https://www.jstor.org/stable/10.5325/style.43.3.341 (18. 06. 2017).

Kadish, Doris. 1975. From Isolation to Integration: Jean Paul Sartre's Le Mur in Modern Language studies. https://www.jstor.org/stable/i360178 (19. 06. 2017).

Lanson, Gustave. 1952. Histoire de la littérature française; remaniée et complétée pour la période 1850-1950 par Paul Tuffrau. Paris: Hachette.

Louette, Jean-François. 2013. Sartre et la mort: 'Le Mur' et après dans: Études françaises 492.

Marfella, Salvatore. 2007. Il Baudelaire di Sartre: un uomo in fuga dalla libertà. http://sens-public.org/article481.html?lang $=f r$ (23. 06. 2017).

Perez, Carmen. 1997. Nouvelles du XX siècle: De l'anthologie au recueil dans: La nouvelle de langue française aux fronières des autres genres, du Moyen Âge à nos jours. Academia Bruylant: 266-272.

Sartre, Jean-Paul. 1972. Le Mur. Paris: Gallimard.

Sartre, Jean-Paul. 1976. Huis Clos suivi de Les Mouches. Paris: Gallimard.

Sartre, Jean-Paul. 1981. Oeuvres romanesques. Paris: Gallimard. 
Sofija S. Janić

\title{
RECUEIL DE NOUVELLES LE MUR DE JEAN-PAUL SARTRE COMME SYMBOLE DE L'IMPOSSIBILITÉ DE RÉALISER LA LIBERTÉ
}

\begin{abstract}
Résumé
"Je pense que je voudrai rentrer dans le mur, je pousserai le mur avec le dos de toutes mes forces et le mur résistera, comme dans les cauchemars" (Sartre 1972 : 16). Le Mur, l'unique recueil de nouvelles de Jean-Paul Sartre, contient les éléments essentiels de sa philosophie: l'absurde, le concept de la mauvaise foi et de l'enfer que sont les autres, ainsi que l'agonie provoquée par le choix libre. On traitera le thème principal du recueil qui est l'impossibilité de la réalisation de la liberté dont les causes sont la fuite devant l'existence et la complexité du rapport avec l'autre représentant l'obstacle à l'authenticité de l'individu. Chaque nouvelle exprime une sorte de fuite devant l'existence, des fuites toujours futiles puisque arrêtées par un mur. En s'appuyant sur les idées de l'existentialisme sartrien, on analysera la manière dont les personnages du recueil, isolés de soi et des autres, en sont le reflet. Ce travail est basé sur l'idée de Sartre selon laquelle la littéraure sera une forme de déstruction du monde dans lequel il n'est pas possible de vivre. Le Mur est destructif parce qu'il détruit la conception bourgeoise du monde : la morale bourgeoise est représentée comme fausse puisque obstacle à la liberté de l'individu, l'existence comme absurde puisque transitoire et l'essence humaine comme inexistante. Pour Dostoïevski, tout est permis si Dieu n'existe pas. Pour Sartre, le si est superflu.
\end{abstract}

Mots clefs : nouvelle, Sartre, existentialisme, liberté, l'autre 
